International Journal of Forensic Science \& Pathology (IJFP)

ISSN 2332-287X

\title{
Consideration for Drug Smuggling/Trafficking
}

Asieh Karimani, Afshari $\mathrm{R}^{*}$

Addiction Research Centre, Mashhad University of Medical Sciences, Mashhad, Iran.

Keywords: Illicit Drugs; Smuggling; Ethics.

\section{*Corresponding Author:}

Reza Afshari,

Addiction Research Centre, Imam Reza Hospital, Ibn-e-Sina Street,

Mashhad, 91735-348, Iran.

Tel: + 985138598973

Fax: + 985138420305

E-mail: AfshariR@mums.ac.ir

Received: April 27, 2015

Accepted: June 20, 2015

Published: July 01, 2015

Citation: Asieh Karimani, Afshari R (2015) Consideration for Drug Smuggling/Trafficking. Int J Forensic Sci Pathol. 3(7), 142-143. doi: http:// dx.doi.org/10.19070/2332-287X-1500034

Copyright: Afshari $\mathbf{R}^{\odot}$ 2015. This is an open-access article distributed under the terms of the Creative Commons Attribution License, which permits unrestricted use, distribution and reproduction in any medium, provided the original author and source are credited.

Not only Iran has one of the highest opium consumption rates [3], but also its long common border with Afghanistan, the world's largest illicit opium producer, has made this country a major part of many illicit drug transition routes. According to UNODC $43 \%$ of worldwide opium use is related to Iran [2].

In the past decades, various methods based on using human's or even animal's body as a container, have been formed and operat- ed for drug smuggling and trafficking. Body packer, body stuffer, body pusher and body container are some of the terms that describe the individuals who are abused in different scenarios of this type of drug trafficking. Table 1 provides more details on definition of these terms [1].

Undoubtedly, these arrangements are not authorized ethically or legally. However, what we, as physicians, are mostly concerned about here is the large number of health risks in the process. Most obviously, the drug packs can be ruptured inside the body due to different reasons, and put the carrier's life in danger. In this case, the medical treatment should be conservative and symptomatic, and the necessity of a surgery must be decided from a combination of clinical findings, progression of symptoms, existence of a powerful antidote such as naloxone, and available health infrastructures.

The mentioned medical risks can vary based on different factors of the situation. As an instance, in the case of body stuffing, since the packs are not safely and professionally prepared, there is a larger amount of risk.

One last important point to be indicated here is that body containers should be protected by authorities. They also need to receive the necessary help regarding their social and psychological heath, in addition to the provided physical care. Social workers can be really helpful in bringing these individuals back to a normal life.

Table 1. Different approaches of drug smuggling/trafficking.

\begin{tabular}{|c|c|c|c|c|}
\hline Terms & Definition & Volume & Health risks & Common places \\
\hline Body packer & $\begin{array}{c}\text { Drugs are precisely wrapped in cellophane packets or condoms } \\
\text { and intentionally swallowed for the purpose of trafficking. }{ }^{[1]}\end{array}$ & +++ & + & $\begin{array}{c}\text { Airports, terminals, } \\
\text { Prison }\end{array}$ \\
\hline Body stuffer & $\begin{array}{c}\text { Drugs are sloppy wrapped in cellophane and swallowed when } \\
\text { encountered with the Police. }\end{array}$ & + & +++ & Streets \\
\hline Body pusher & $\begin{array}{c}\text { Drugs are wrapped in cellophane packets and pushed into } \\
\text { rectum or vagina for the purpose of trafficking. }\end{array}$ & ++ & + & Prison \\
\hline Body container & $\begin{array}{c}\text { Precisely wrapped packets are given to mentally incapacitated } \\
\text { subjects, children, or live animals for the purpose of smuggling. }\end{array}$ & +++ & + & N/A \\
\hline Carrier & $\begin{array}{c}\text { Animals such as mules are made to be addict and trained for } \\
\text { travel across the borders. They are loaded with illicit drugs. } \\
\text { Upon their arrival they are given opium to control withdrawal. }\end{array}$ & +++ & Borders \\
\hline 1]. Pregnant women are at higher risk to be used by smugglers, as it is harder to pick them up due to potential sympathy of the police and limitation of using $X$ rays.
\end{tabular}

They should be treated, however, as high risk 


\section{References}

[1]. Afshari R, Monzavi SM (2012) Venomous animals and arthropods envenomation [in Persian]: Afshari's Clinical Toxicology and Poisoning Emergency Care. ( $2^{\text {nd }}$ edn), Mashhad University of Medical Sciences Publication, Mashhad, Iran. 221-241.
[2]. Annual Report of United Nations Office on Drugs and Crime. World Drug Report. Retrieved December 142014 from https://www.unodc.org/documents/wdr2014/World_Drug_Report_2014_web.pdf

[3]. Tashakori A, Afshari R (2010) Tramadol overdose as a cause of serotonin syndrome: a case series. Clin Toxicol 48(4): 337-341. 